\title{
THE PHYSICAL ACTIVITY LEVEL DECLARED BY STUDENTS FROM BELARUS
}

\section{POZIOM DEKLAROWANEJ AKTYWNOŚCI FIZYCZNEJ STUDENTÓW Z BIAŁORUSI}

\author{
Joanna Baj-Korpak ${ }^{1(\mathrm{~A}, \mathrm{~B}, \mathrm{D}, \mathrm{E}, \mathrm{F}, \mathrm{G})}$, Andrei Shpakou $^{2(\mathrm{~A}, \mathrm{~B}, \mathrm{D}, \mathrm{E}, \mathrm{F})}$, Adam Szepeluk $\mathbf{K}^{3(\mathrm{~A}, \mathrm{~B}, \mathrm{C}, \mathrm{G})}$ \\ ${ }^{1}$ Department of Physiotherapy, Pope John Paul II State School of Higher Education in Biała Podlaska, Poland \\ ${ }^{2}$ Department of Sport Medicine and Rehabilitation, Yanka Kupala State University of Grodno, Belarus \\ ${ }^{3}$ Department of Computer Science, Pope John Paul II State School of Higher Education in Biała Podlaska, Poland
}

Authors' contribution Wkład autorów: A. Study design/planning zaplanowanie badań B. Data collection/entry zebranie danych

C. Data analysis/statistics dane - analiza i statystyki D. Data interpretation interpretacja danych E. Preparation of manuscript przygotowanie artykułu F. Literature analysis/search wyszukiwanie i analiza literatury G. Funds collection zebranie funduszy

\section{Summary}

Background. Numerous connections of physical activity with biological indicators and various diseases justify its place in the multifaceted theory of health, thus making it a health measure. The aim of the study was to learn about the physical activity declared by students at Belarusian universities - to determine its level and dominant areas.

Material and methods. 739 people studying in Brest, Minsk, and Grodno (Belarus) were surveyed with the long version of the International Physical Activity Questionnaire (IPAQ).

Results. The total physical activity of the surveyed students amounted to 4840.5 metabolic equivalent of task (MET) min/week (median), which proves their significant involvement in the broadly understood physical culture. The dominant area of their physical activity proved to be work-related effort (median=1700.6 MET-min/week), while the lowest activity of the respondents was related to sport and recreation. The surveyed men showed higher MET-min/week rates in total physical activity and its components compared with women except for housework. In each of the analyzed variables (gender, Body Mass Index (BMI), selfassessment of physical fitness, and declared amount of spare time), there were statistically significant differences in the physical activity level of the surveyed students.

Conclusions. The surveyed men proved to be more active than women in all domains of physical activity except for housework. Respondents with a BMI indicating overweight were more active than those with a normal BMI or those who were underweight. High self-esteem and declaration of lacking spare time are associated with high values of the MET-min/week index.

Keywords: students, physical activity, IPAQ, Belarus

\section{Streszczenie}

Wprowadzenie. Liczne powiązania aktywności fizycznej ze wskaźnikami biologicznymi i różnymi jednostkami chorobowymi uzasadniają jej miejsce w wieloaspektowej teorii zdrowia, tym samym czynią ją swego rodzaju miernikiem zdrowia. Celem prezentowanej pracy było poznanie deklarowanej przez studentów białoruskich uczelni aktywności fizycznej określenie jej poziomu oraz wskazanie dominujących obszarów.

Materiał i metody. Sondażem diagnostycznym z wykorzystaniem długiej wersji Międzynarodowego Kwestionariusza Aktywności Fizycznej (IPAQ) objęto 739 osób studiujących w Brześciu, Mińsku i Grodnie (Białoruś).

Wyniki. Wielkość deklarowanej całkowitej aktywności fizycznej badanych studentów wyniosła 4840,5 MET-min./tydzień (mediana), co świadczy o ich znacznym zaangażowaniu w szeroko pojętą kulturę fizyczną. Dominujacym obszarem aktywności fizycznej okazały się wysiłki związane z pracą (mediana=1700,6 MET-min./tydzień), najniższą aktywność ankietowanych odnotowano w obrębie wysiłków o związanych ze sportem i rekreacją. Badani mężczyźni w porównaniu do badanych kobiet prezentowali wyższe wskaźniki MET-min./ tydzień w obszarze całkowitej aktywności fizycznej i jej składowych, z wyjątkiem wysiłków związanych z pracami domowymi. W każdej z analizowanych zmiennych (płeć, BMI, samoocena sprawności fizycznej, deklarowana ilość wolnego czasu) wystąpiło istotne statystycznie zróżnicowanie poziomu aktywności fizycznej badanych studentów.

Wnioski. Badani mężczyźni okazali się być aktywniejsi od kobiet we wszystkich domenach aktywności fizycznej oprócz prac domowych. Ankietowani z BMI wskazującym na nadwagę byli bardziej aktywni niż osoby z BMI w normie lub osoby z niedowagą. Wysoka samoocena i deklaracja nieposiadania wolnego czasu przez badaną młodzież wiąże się z wysokimi wartościami wskaźnika MET-min./tydzień.

Słowa kluczowe: studenci, aktywność fizyczna, IPAQ, Białoruś
Figures: 1

References: 51

Submitted: 2020 Dec 18

Accepted: 2021 March 8

Baj-Korpak J, Shpakou A, Szepeluk A. The physical activity level declared by students from Belarus. Health Prob Civil. 2021; 15(2): 122-130. https://doi.org/10.5114/hpc.2021.104553

Address for correspondence / Adres korespondencyjny: Joanna Baj-Korpak, Department of Physiotherapy, Pope John Paul II State School of Higher Education, Sidorska 95/97, 21-500 Biała Podlaska, Poland, e-mail: joanna.baj.korpak@interia.pl, phone: +48 833449900

ORCID: Joanna Baj Korpak https://orcid.org/0000-0002-6379-2485, Andrei Shpakou https://orcid.org/0000-0003-4340-5211,

Adam Szepeluk https://orcid.org/0000-0003-0406-3423

Copyright: (C) Pope John Paul II State School of Higher Education in Biała Podlaska, Joanna Baj-Korpak, Andrei Shpakou, Adam Szepeluk. This is an Open Access journal, all articles are distributed under the terms of the Creative Commons Attribution-NonCommercial-ShareAlike 4.0 International (CC BY-NC-SA 4.0) License (http://creativecommons.org/licenses/by-nc-sa/4.0/), allowing third parties to copy and redistribute the material in any medium or format and to remix, transform, and build upon the material, provided the original work is properly cited and states its license. 


\section{Introduction}

Physical activity plays an important role in shaping human health and proper development. The human body is designed to move, hence there is a need, or even the necessity, to undertake a systematic physical activity. Movement is an inseparable component of modern human life: it affects the proper functioning of the body, positively influences our psyche and our general well-being [1]. St. Thomas Aquinas already noticed the need to undertake physical activity by saying that "[e]very man has a duty to take care of his own body". Thus, quoting Demel [2], any physical activity cannot be "stranded on one's spare time".

Physical activity is a well-known term, but it is difficult to define. According to Kozłowski and Nazar [3], it is a physical effort consisting in the work of skeletal muscles along with all accompanying functional changes in the body. It is a movement induced by the strength of skeletal muscles, which results in energy expenditure at a level higher than the rate of resting metabolism [4-6].

The need to systematically undertake physical activity is commonly emphasized as a manifestation of a healthy lifestyle [7,8]. A sedentary lifestyle uncompensated by a sufficient dose of exercise is becoming an increasing public health problem.

Hypokinesia, that is lack of movement, is considered to be one of the important causes of ischemic heart diseases [9,10] and neoplastic diseases [11]. The consumptive lifestyle multiplies the human behavior that is physically passive. Uncritical adherence to contemporary trends by displaying 'anti-health' behaviors from an early age deforms the development of the organism, and thus impairs health and contributes to the acceleration of involutional changes in the organism [12]. Most of the physical activities undertaken by humans are related to work, study, or everyday activities but the constant development of civilization, and thus new technological achievements, mean that the energy expenditure allocated to these activities is constantly decreasing. This decrease in activity leads to hypokinesia [7]. According to Kozłowski [13], movement is a biological necessity both in the preventive and therapeutic approach, especially in the case of a sedentary, overfed, and often overly excited person.

Physical activity plays a key role in promoting physical, mental, and social health. Hence, its measurement becomes a necessity and, at the same time, a challenge for researchers from the all over the world [14-16]. Systematic and properly selected physical activity is one of the most recommended health-promoting behaviors for humans. Determining the physical activity level provides data for the development and improvement of theoretical models of behavior, which allow for the formulation of specific postulates on the promotion of physical activity [17-19].

In epidemiological studies, a diagnostic survey is a popular method of estimating the physical activity level, and questionnaires are the measurement tools [17]. One of the most used and recommended questionnaires is the IPAQ [20]. Its advantages are: simple testing procedures and short filling time. Globally standardized test procedures developed by the International IPAQ Committee allow for the widespread use of this tool, and the results obtained are comparable in various cases [21,22]. The benefit of monitoring physical activity is the feedback on the undertaken physical activity level, which, on the one hand, allows for interpretation in relation to the health-promoting recommendations of physical activity, and on the other hand, is a factor that motivates to do physical exercise [17]. However, that tool is not widely used in Belarus [23], hence there is a need to conduct further research with comparable results.

The aim of the study was to learn about the physical activity declared by students at Belarusian universities - to determine its level and dominant areas.

\section{Material and methods}

\section{Respondents}

The study covered 739 people studying in Brest, Minsk, and Grodno (Belarus). The age of the respondents ranged from 17 to 46 years. Their mean age was $18.6 \pm 3.3$ years. Women accounted for $75.8 \%$ of all respondents. The students from Grodno constituted the largest group - nearly 63\% - of all respondents. The study covered students of various faculties grouped into four categories: humanistic, medical, technical, and sports. The vast majority were respondents studying humanities (78.6\%). Of the five years of study, the most numerous groups were first-year students (62.9\%) and the least numerous were fourth-year students (3.2\%). Detailed data characterizing the studied group are presented in Tables 1 and 2. 
Table 1. Size and diversity of selected biometric indicators

\begin{tabular}{|c|c|c|c|c|c|c|}
\hline Variable & Group & $\mathbf{n}$ & $\overline{\mathbf{x}}$ & $\mathbf{S D}$ & Min & Max \\
\hline \multirow{3}{*}{ AG [years] } & Total & 739 & 18.6 & 3.3 & 17.0 & 46.0 \\
\cline { 2 - 7 } & Female & 560 & 18.5 & 3.4 & 17.0 & 46.0 \\
\cline { 2 - 7 } & Male & 179 & 18.9 & 3.1 & 17.0 & 42.0 \\
\hline \multirow{3}{*}{ BH [cm] } & Total & 739 & 170.2 & 8.2 & 142.0 & 201.0 \\
\cline { 2 - 7 } & Female & 560 & 167.1 & 5.8 & 142.0 & 194.0 \\
\cline { 2 - 7 } & Male & 179 & 179.8 & 7.3 & 161.0 & 201.0 \\
\hline \multirow{3}{*}{ BM [kg] } & Total & 739 & 60.6 & 11.0 & 37.0 & 125.0 \\
\cline { 2 - 7 } & Female & 560 & 57.3 & 8.4 & 37.0 & 125.0 \\
\cline { 2 - 7 } & Male & 179 & 71.2 & 11.6 & 50.0 & 113.0 \\
\hline \multirow{3}{*}{ BMI [kg/m $\mathbf{2}]$} & Total & 739 & 20.8 & 2.8 & 14.3 & 43.3 \\
\cline { 2 - 7 } & Female & 560 & 20.5 & 2.7 & 14.3 & 43.3 \\
\cline { 2 - 7 } & Male & 179 & 22.0 & 2.9 & 16.6 & 31.6 \\
\hline
\end{tabular}

Notes: $\mathrm{n}$ - number of cases, $\overline{\mathrm{x}}$ - arithmetic mean, SD - standard deviation, Min - minimum score, Max - maximum score, $\mathrm{AG}$ - age, BH - height, BM - body mass, BMI - Body Mass Index.

Table 2. The number and percentage of physically active participants in the groups according to socio-demographic indicators

\begin{tabular}{|c|c|c|c|}
\hline \multirow{2}{*}{ Variable } & \multirow{2}{*}{ Category } & \multicolumn{2}{|c|}{ Total } \\
\hline & & $\mathbf{n}$ & $\%$ \\
\hline \multirow{2}{*}{ Gender } & Female & 560 & 75.8 \\
\hline & Male & 179 & 24.2 \\
\hline \multirow{3}{*}{ Place of study } & Minsk & 263 & 35.6 \\
\hline & Grodno & 465 & 62.9 \\
\hline & Brest & 11 & 1.5 \\
\hline \multirow{4}{*}{ Faculties } & Humanistic & 581 & 78.6 \\
\hline & Medical & 11 & 1.5 \\
\hline & Technical & 58 & 7.8 \\
\hline & Sports & 89 & 12.0 \\
\hline \multirow{5}{*}{ Year of studies } & First & 465 & 62.9 \\
\hline & Second & 124 & 16.8 \\
\hline & Third & 86 & 11.6 \\
\hline & Fourth & 24 & 3.2 \\
\hline & Fifth & 40 & 5.4 \\
\hline \multirow{3}{*}{ Self-assessment of physical fitness } & Low & 92 & 12.4 \\
\hline & Moderate & 553 & 74.8 \\
\hline & High & 94 & 12.7 \\
\hline \multirow{3}{*}{ Amount of declared spare time } & Enough & 342 & 46.3 \\
\hline & Too small & 299 & 40.5 \\
\hline & Lack of spare time & 98 & 13.3 \\
\hline
\end{tabular}

Notes: $\mathrm{n}$ - number of cases, $\%$ - percentage of respondents.

Since the extreme categories of the Body Mass Index (BMI) variable contained minimal numbers of respondents, the variable was categorized into three values: underweight, normal value, and overweight (Table 3). The values of the BMI variable and its particular categories were calculated based on Szczeklik's classification [24]. The average BMI value both for the whole group of respondents and according to gender was in the range of $18.5-24.9 \mathrm{~kg} / \mathrm{m}^{2}$.

Table 3. The number and percentage of respondents based on BMI

\begin{tabular}{|c|c|c|c|}
\hline \multirow{2}{*}{ Variable } & Category & \multicolumn{2}{|c|}{ Total } \\
\cline { 3 - 4 } & & $\mathbf{n}$ & \% \\
\hline \multirow{2}{*}{ BMI } & Underweight $\left(\leq 18.4 \mathrm{~kg} / \mathrm{m}^{2}\right)$ & 141 & 19.1 \\
\cline { 2 - 4 } & Normal value $\left(18.5-24.9 \mathrm{~kg} / \mathrm{m}^{2}\right)$ & 537 & 72.7 \\
\cline { 2 - 4 } & Overweight $\left(\geq 25.0 \mathrm{~kg} / \mathrm{m}^{2}\right)$ & 61 & 8.3 \\
\hline
\end{tabular}

Notes: $\mathrm{n}$ - number of cases, $\%$ - percentage of respondents. 


\section{Study design}

The study consisted in a diagnostic survey using an auditorium (environmental) questionnaire, conducted individually at respondents' place of study. The long version of IPAQ was used [20]. For the purpose of this study, questions about the self-assessment of the physical activity level were added to the IPAQ metric. Respondents completed the online questionnaire in the presence of trained interviewers. According to Bergier et al. [21], it is a requirement necessary to conduct reliable research. The presence of a trained interviewer gives the opportunity to discuss the essence of the study and allows for ongoing instruction and clarification of emerging doubts.

\section{Statistical analysis}

The collected data were statistically analyzed in the Statistica 10.0 PL programme. Certain descriptive and decision-making tools were used to describe the collected study material. These tools helped to determine the reliability of the relationships found in the sample and the possibility of their generalization to the entire population. The data deviated from the normal distribution (the distributions of variables were analyzed with the Shapiro-Wilk test). The Mann-Whitney U test was used to examine the differences in the value of the metabolic equivalent of task (MET) min/week index in terms of gender and place of residence. Kruskal-Wallis test was used for more than two predictors. The level of significance was $p<0.05$ in all the analyzed cases.

\section{Results}

Self-assessment of respondents' physical fitness may be an interesting criterion for analyzing their level of physical activity. It was found that almost three-quarters of the respondents described themselves as moderately physically fit (Table 2). The remaining respondents were people with a high (12.7\%) and low (12.4\%) assessment of their physical fitness.

Determining the level of physical activity undertaken by the students can be a measure of the consumption of their spare time. Almost half of the respondents declared the amount of their spare time as sufficient, $40.5 \%$ of the respondents have too little of it, and $13.3 \%$ of them declare its lack.

The study results obtained with the IPAQ showed that the respondents from Belarus present a satisfactory level of physical activity. Their total physical activity was as high as 4840.5 MET-min/week (median). Work/ study effort proved to be the dominant area (1700.6 MET-min/week). The students were the least active in sport and recreation (Figure 1).

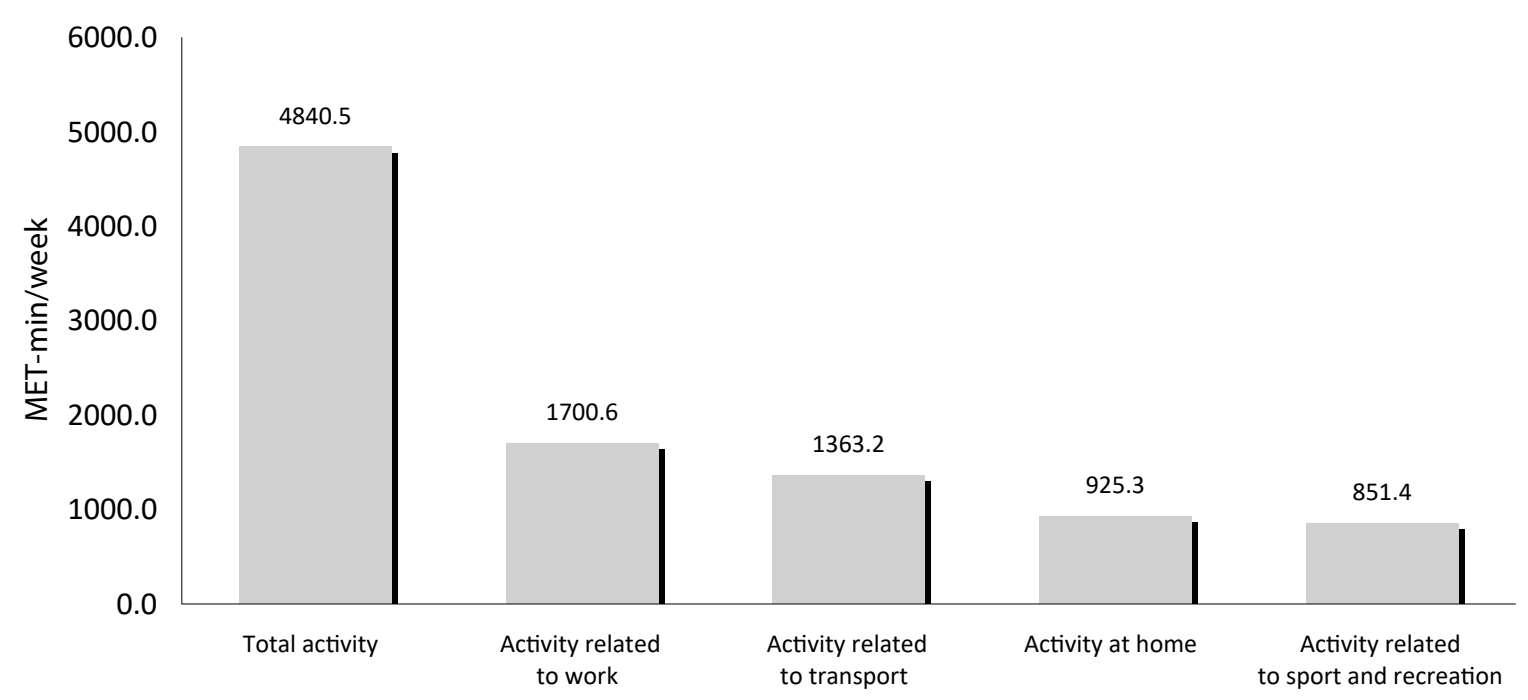

Figure 1. The level of total physical activity declared and its areas (domains)

The value of the MET-min/week index and the gender criterion were taken to account. As a result, statistically significant differences were observed in the total physical activity and areas related to work and transport. Higher values of MET-min/week index were recorded in the group of men than women (Table 4). The exception was the activity related to housework, where higher MET-min/week values were reported in women (540 MET$\mathrm{min} /$ week in women and $420 \mathrm{MET}-\mathrm{min} /$ week in men). 
Table 4. The level of total and type of physical activity (expressed as median values) in relation to the selected characteristics of the respondents (MET-min/week)

\begin{tabular}{|c|c|c|c|c|c|c|}
\hline \multirow{2}{*}{\multicolumn{2}{|c|}{ Characteristics of the respondents }} & \multicolumn{5}{|c|}{ Domains of physical activity } \\
\hline & & \multirow{2}{*}{$\frac{\text { Total }}{3433.5^{2}}$} & \multirow{2}{*}{\begin{tabular}{|c|} 
Work-related \\
$899.3^{2}$
\end{tabular}} & \multirow{2}{*}{$\begin{array}{c}\text { Transport } \\
\mathbf{8 0 0 . 3 ^ { 2 }} \\
\end{array}$} & \multirow{2}{*}{$\begin{array}{c}\text { Housework } \\
540.0 \\
\end{array}$} & \multirow{2}{*}{$\begin{array}{c}\begin{array}{c}\text { Sport and } \\
\text { leisure }\end{array} \\
460.5 \\
\end{array}$} \\
\hline \multirow{3}{*}{ Gender } & Female & & & & & \\
\hline & Male & $5118.0^{1}$ & $1215.0^{1}$ & $1284.0^{1}$ & 420.0 & 678.0 \\
\hline & TEST & $\begin{array}{c}\mathrm{Z}=2.95 \\
\mathrm{p}=0.0032\end{array}$ & $\begin{array}{c}\mathrm{Z}=2.37 \\
\mathbf{p}=0.0178\end{array}$ & $\begin{array}{c}\mathrm{Z}=2.45 \\
\mathrm{p}=0.0143\end{array}$ & $\begin{array}{c}\mathrm{Z}=1.04 ; \\
\mathrm{p}=0.2970\end{array}$ & $\begin{array}{c}\mathrm{Z}=1.72 \\
\mathrm{p}=0.0845\end{array}$ \\
\hline \multirow{4}{*}{ BMI } & Underweight & $2658.0^{3}$ & 819.0 & $693.0^{3}$ & $360.0^{3}$ & 372.0 \\
\hline & Normal & 3952.5 & 967.5 & 924.0 & 540.0 & 480.0 \\
\hline & Overweight & $5515.0^{1}$ & 1215.0 & $1188.0^{1}$ & $600.0^{1}$ & 693.0 \\
\hline & TEST & $\begin{array}{c}\mathbf{H}=8.95 ; \\
\mathbf{p}=0.0114\end{array}$ & $\begin{array}{c}\mathrm{H}=2.62 ; \\
\mathrm{p}=0.2705\end{array}$ & $\begin{array}{c}\mathrm{H}=6.78 ; \\
\mathrm{p}=0.0337\end{array}$ & $\begin{array}{c}H=6.14 \\
p=0.0464\end{array}$ & $\begin{array}{c}\mathrm{H}=3.32 \\
\mathrm{p}=0.1897\end{array}$ \\
\hline \multirow{4}{*}{$\begin{array}{l}\text { Self-assessment of } \\
\text { physical fitness }\end{array}$} & Low & $2495.8^{3}$ & 720.0 & 717.8 & $347.5^{3}$ & $240.0^{3}$ \\
\hline & Moderate & 3796.0 & 963.0 & 924.0 & 540.0 & $480.0^{3}$ \\
\hline & High & $6245.0^{1}$ & 1363.5 & 1188.0 & $720.0^{1}$ & $1029.0^{1.2}$ \\
\hline & TEST & $\begin{array}{c}\mathrm{H}=13.30 \\
\mathrm{p}=0.0013\end{array} *$ & $\begin{array}{c}\mathrm{H}=4.91 \\
\mathrm{p}=0.0858\end{array}$ & $\begin{array}{c}\mathrm{H}=4.12 ; \\
\mathrm{p}=0.1276\end{array}$ & $\begin{array}{c}H=6.55 \\
p=0.0378\end{array}$ & $\begin{array}{c}\mathrm{H}=13.97 \\
\mathbf{p}=0.0009\end{array}$ \\
\hline \multirow{4}{*}{$\begin{array}{l}\text { Amount of declared } \\
\text { spare time }\end{array}$} & Enough & $4281.0^{2}$ & $1049.3^{2}$ & 1056.8 & 510.0 & $558.4^{2}$ \\
\hline & Too small & $2964.0^{1.3}$ & $801.0^{1.3}$ & 792.0 & 532.5 & $388.5^{1.3}$ \\
\hline & None & $4555.5^{2}$ & $1462.5^{2}$ & 924.0 & 530.0 & $685.5^{2}$ \\
\hline & TEST & $\begin{array}{c}\mathrm{H}=11.54 ; \\
\mathbf{p}=\mathbf{0 . 0 0 3 1}\end{array}$ & $\begin{array}{c}\mathrm{H}=10.37 \\
\mathbf{p}=\mathbf{0 . 0 0 5 6}\end{array}$ & $\begin{array}{c}H=5.11 \\
p=0.0776\end{array}$ & $\begin{array}{c}H=0.63 \\
p=0.7303\end{array}$ & $\begin{array}{c}\mathrm{H}=9.15 ; \\
\mathrm{p}=0.0103\end{array}$ \\
\hline
\end{tabular}

Notes: Z - Mann-Whitney U value, H - Kruskal-Wallis value, * - significant differentiation at $\mathrm{p}<0.05$.

The BMI value statistically significantly differentiated the values of the MET-min/week index within the total physical activity and within the domain related to movement (transport) and housework. These differences were present in underweight and overweight respondents. The respondents whose BMI value indicated overweight proved to be more active. There were no statistically significant differences between the groups with BMI indicating overweight, underweight, or normal BMI in the case of work-related activities, and sports and leisure activities. The least active in these areas were students with BMI below $18.5 \mathrm{~km} / \mathrm{m}^{2}$.

It was interesting to learn about the self-assessment of the physical activity level by the examined youth. The students were asked to make a subjective assessment of the presented level of physical activity. It was found that respondents with a high self-esteem achieved higher MET-min/week values compared with those who assessed themselves as moderately active and physically inactive. Statistically significant differences occurred between respondents with a high and low self-esteem of physical fitness in the total physical activity and areas related to work in the house and on their own backyard. Those differences were in favor of the highly active respondents. The level of self-esteem significantly differentiated the physical activity levels related to sport and leisure. In this case, the difference occurred between students with a high level of physical fitness and students with a moderate and low self-esteem. Self-assessment of physical fitness did not produce statistically significant differences in the values of the MET-min/week index related to work and transport. However, the correlation has been confirmed that the higher the self-esteem, the higher the physical activity index.

The respondents declaring lack of spare time proved to be the most active. The average value of the METmin/week index in this group was 4555.5. Statistically significant differences occurred between the group of students declaring sufficient spare time, the group declaring a small amount of spare time, and the students who lacked spare time. Taking to account the physical activity domains, statistically significant differences between the three categories occurred within two areas: work, and sports and leisure. In both cases, the highest values of the MET-min/week index were recorded in the group declaring lack of spare time, and the lowest values were recorded by those declaring too little time available to them. Transport and housework are domains in which no statistically significant differences in the physical activity level were found.

\section{Discussion}

Until recently, physical activity was treated with considerable reserve by both theoreticians and practitioners in terms of effective prophylaxis and treatment. However, it is well known that a sedentary lifestyle, and thus 
a low level of physical activity, are risk factors for many diseases [25-27]. Unfortunately, as it has been noticed by, among others, Sas-Nowosielski [28] and Biernat [29], everyday physical culture is entering the life of a modern human very slowly, and the adaptation process varies depending on the social group and its factors.

The results of this study are in line with the current, but still insufficiently developed, area of research on physical activity, especially that of the young generation entering adulthood. The level of the broadly understood physical culture in a given society will largely depend on the young generation.

The literature highlights the complexity of the physical activity assessment process and the multi-faceted analysis of its level $[17,30,31]$. Such research should take to account many factors, including: age, gender, somatic parameters, and motives for physical activity. Research on physical activity across social groups, including cross-sectional research, gives a picture of the population health. It makes it possible to define the 'direction' of respondents' lifestyle. In other words, such research may indicate whether pro-health behaviors compliant with common recommendations are displayed. Such an analysis may also be a premise for an individualized action $[17,22]$.

According to the current recommendations of the WHO regarding physical activity, adults (18-64 years) should spend 150-300 minutes a week on moderate physical activity or do 75-150 minutes of high-intensity exercise [32]. It is estimated that one in four (27.5\%) adults [33] and over three-fourths (81\%) of adolescents [34] fail to meet the global recommendations for aerobic exercise [35]. The STEPS 2016 study conducted among 5010 respondents from Belarus indicates that one in eight Belarusians (13.2\%) was not physically active enough and failed to meet WHO recommendations for physical exercise to maintain or improve health. Such a tendency increases the risk of non-communicable diseases [36]. The results of surveys conducted among students in Russia and Kazakhstan [37] show that these countries currently lag far behind developed countries, where up to $40 \%-50 \%$ of the population systematically undertake physical activity. In the eastern countries, active people account for $11 \%$ of the population [38]. Recent studies show that health promotion and protection are the priority needs of young people in Russia [38,39]. Thus, there is a strong need to promote physical activity, especially among young people, who are the 'backbone' of the new generation. The results of this study demonstrate that the surveyed students from Belarus are aware of the need to be active, which is confirmed by the average MET$\mathrm{min} /$ week ratio at the level of 4840.5 .

According to Bull et al. [40], global trends [32-34,41] over the last two decades fail to indicate a general improvement in the level of society's participation in the broadly understood physical culture, and there are no significant differences in this respect in favor of either gender. There are, however, significant differences between the genders in the frequency of engaging in health-promoting behaviors [42]. It is worth noting that in terms of the physical activity level, female adolescents perform worse than young men $[43,44]$. The results of the studies published by the WHO [36] indicate that Belarusian men were 1.5 times more active than women. Our own study also showed that male students undertook more physical activity (5118.0 MET-min/week) than female students (3433.5 MET-min/week), which confirms other studies conducted with the IPAQ [45-47].

Adolescents become less active with age due to the growing number of other, mainly sedentary, activities, related both to learning and leisure time [48,49]. This is also confirmed by the results of the STEPS 2016 study [36]. Moreover, global data consistently indicate inequalities in the physical activity level in terms of age, gender, disability, socio-economic status, or origin [50]. In studies on the dissemination of risk factors for noncommunicable diseases in Belarus [36], men showed higher activity in the area of professional work. The results of this study confirm this relationship. The 2016 STEPS report [36] showed that more than half of the time (54.4\%) devoted by Belarusians to physical activity was spent on transport, while our own study indicates the predominance of work/study activities (35\%). The transport area accounted for $28 \%$ of the total physical activity.

The research results by DiPietro et al. emphasize the need to intensify promotion of health-promoting behaviors [51]. After all, any form of physical activity is more beneficial than its lack [40].

\section{Study limitations}

The study was conducted with the IPAQ, thus providing an analysis of the subjective declarations of students. In the subsequent studies on the physical activity level, it is worth considering the accelerometer, which is an objective measuring tool. This will allow to assess the compliance of the IPAQ with respondents' weekly energy expenditure determined based on the results from the accelerometer. However, the implementation of such research requires obtaining funds for the measuring devices. 


\section{Conclusions}

The surveyed students from Belarus present a satisfactory level of physical activity and meet the WHO recommendations in this regard.

The surveyed youth from Belarus mainly undertakes 'compulsory' physical activity. Of the analyzed areas of physical activity, the dominant area proved to be professional work and learning, that is physical activities related to the study programme. Respondents showed the lowest activity in terms of sport and recreation, which may indicate their low need to undertake spare-time physical activity.

The determinants included in the statistical analysis (gender, BMI, self-assessment of the level of physical fitness, and the amount of spare time) statistically significantly differentiated the value of the MET-min/week index. The surveyed men proved to be more active than women in all domains of physical activity except for housework. Respondents with a BMI indicating overweight were more active than those with a normal BMI or those who were underweight. High self-esteem and declaration of lacking spare time were associated with high values of the MET-min/week index. The higher the self-assessment of physical fitness, the higher respondent's physical activity. The level of self-esteem is a factor that significantly reflects the physical activity level.

\section{Disclosures and acknowledgments}

The work was created under the Grants Fund for Own Research FG.IV.4 "Physical activity and nutritional behavior of students and schoolchildren in Belarus". The project manager was Professor Józef Bergier.

\section{References:}

1. Kiełbasiewicz-Drozdowska I, Wiza A. [Physical recreation of teachers: needs - motives - benefits. Research report]. In: Dąbrowski A., editor. [Participation of Poles in the physical recreation and its conditioning]. Płock: AWF, Szkoła Wyższa im. Pawła Włodkowica; 2003 (in Polish).

2. Demel M. [Repetitions. Selected issues in physical activity, health and education]. Warszawa: AWF; 2008 (in Polish).

3. Kozłowski S, Nazar K. [Introduction to clinical physiology]. Warszawa: Wydawnictwo Lekarskie WZWL; 1999 (in Polish).

4. Caspersen CJ, Powell K, Christenson G. Physical activity, exercise and physical fitness: definitions and distinctions for health - related research. Public Health Reports. 1985; 100(02): 126-131.

5. Bouchard C, Blair SN. Why study physical activity and health?. In: Bouchard C, Blair SN, Haskell W., editors. Physical activity and health. Champaign, IL: Human Kinetics; 2007.

6. Sygit K, Sygit M, Pielichowska E, Sygit-Kowalkowska E. Constitutive importance of lifestyle in health protection and promotion. Hygeia Public Health. 2014; 49(4): 665-671.

7. Marchewka A, Jungiewicz M. [Physical activity in early years of life versus quality of life in old age]. Gerantologia Polska. 2008; 16(2): 127-130 (in Polish).

8. Zheleznyak YD, Leifa AV, Perel'man IM. [Interconnection of physical activity, health and life quality of students]. Teoriia i praktika fizicheskoj kul'tury. 2015; 11: 41-43 (in Russian).

9. Zdrojewski T, Bandosz P, Szpakowski P, Konarski R, Manikowski A, Wołkiewicz E, et al. [Prevalence of the main risk factors for cardiovascular diseases in Poland. NATPOL PLUS research results]. Kardiol Pol. 2004; 61(Suppl. 4): 1-26 (in Polish).

10. Janssen I. Physical activity, fitness, and cardiac, vascular, and pulmonary morbidities. In: Bouchard C, Blair SN, Haskell WL., editors. Physical activity and health. Champaign, IL: Human Kinetics; 2007: 161-172.

11. Mao Y, Pan S, Wen SW, Johnson KC. Physical activity and the risk of lung cancer in Canada. Am J Epidemiol. 2003; 158: 564-575. https://doi.org/10.1093/aje/kwg186

12. Pańczyk W. [Physical education for health. Physical activity in the face of the health needs of a human in the consumption civilization]. Rzeszów: Wydawnictwo Uniwersytetu Rzeszowskiego; 2012 (in Polish).

13. Kozłowski S. [Physiopathology of physical efforts]. Warszawa: PWN; 1971 (in Polish).

14. Biernat E, Piątkowska M. Stay active for life - physical activity across life stages. Clinical Interventions in Aging. 2018; 13: 1341-1352. https://doi.org/10.2147/CIA.S167131

15. Biernat E, Buchholtz S. The regularities in insufficient leisure-time physical activity in Poland. Int J Environ Res Public Health. 2016; 13: 798. https://doi.org/10.3390/ijerph13080798

16. Harris J. Physical education teacher education students' knowledge, perceptions and experiences of promoting healthy, active lifestyles in secondary schools. Physical Education and Sport Pedagogy. 2014; 19(5): 466-480. https://doi.org/10.1080/17408989.2013.769506 
17. Cholewa J, Witkowski M, Wąsik J, Góra T. Declared and actual students' physical activity. Physical Education of Students. 2020; 24(3): 135-140. https://doi.org/10.15561/20755279.2020.0302

18. Gorzkowska A, Cholewa J, Małecki A, Klimkowicz-Mrowiec A, Cholewa J. What determines spontaneous physical activity in patients with Parkinson's disease?. Journal of Clinical Medicine. 2020; 9: 1296. https://doi.org/10.3390/jcm9051296

19. Jones GJ, Carlton T, Hyun M, Kanters M, Bocarro J. Assessing the contribution of informal sport to leisuretime physical activity: a new perspective on social innovation. Managing Sport \& Leisure. 2020; 25(3): 161174. https://doi.org/10.1080/23750472.2019.1620627

20. International Physical Activity Questionnaire (IPAQ) [Internet]. Stockholm: Karolinska Institutet; 2002 [cited 2020 Aug 18]. Available from: www.ipaq.ki.se.

21. Bergier J, Kapka-Skrzypczak L, Biliński P, Paprzycki P, Wojtyła A. Physical activity of Polish adolescents and young adults according to IPAQ: a population based study. Ann Agric Environ Med. 2012; 19(1): 109-115.

22. Drygas W, Bielecki W, Puska P. Assessment of physical activity of populations of 6 European countries under the „Bridging East-West Health Gap” Project. Polish Journal of Sport Medicine. 2002; 18(5): 169-174.

23. Koleda V, Kulikov V, Novitskaya V. [Monitoring of students' physical activity as a basis for assessing the quality of general physical education]. Vysheyshaya shkola. 2019; 5: 14-17 (in Russian).

24. Szczeklik A. [Internal diseases. Vol. 1, 2]. Kraków: Medycyna Praktyczna; 2005 (in Polish).

25. Drygas W. [Physical effort - panacea, myth or catastrophe]. Medicina Sportiva. 1997; 1(1): 37-44 (in Polish).

26. Bertoldi AD, Hallal PC, Barros AJ. Physical activity and medicine use: evidence from a population-based study. BMC Public Health. 2006; 6: 224. https://doi.org/10.1186/1471-2458-6-224.

27. Derbyshire E, Davies J, Costarelli V, Dettmar P. Diet, physical inactivity and the prevalence of constipation throughout and after pregnancy. Maternal and Child Nutrition. 2006; 2(3): 127-134. https://doi.org/10.1111/j.1740-8709.2006.00061.x

28. Sas-Nowosielski K. [Contemporary views on the topic of the physical activity determinants and their implications in pedagogy]. Wychowanie Fizyczne i Zdrowotne. 2003; 8-9: 3-8 (in Polish).

29. Biernat E. [Physical activity of inhabitants of Warsaw. A study of some professional groups]. Warszawa: Szkoła Główna Handlowa; 2011 (in Polish).

30. Pacesova P, Smela P, Kracek S. Personal wellbeing as part of the quality of life: is there a difference in the personal well-being of women and men with higher level of anxiety trait regarding their sport activity?. Physical Activity Review. 2019; 7: 201-208. https://doi.org/10.16926/par.2019.07.24

31. Leifa A, Zheleznyak Y. Influence of physical activity on students' life quality. Physical Education of Students. 2017; 21(5): 244-248. https://doi.org/10.15561/20755279.2017.0507

32. World Health Organization. Guidelines for physical activity and sedentary behaviour. Geneva: World Health Organization; 2020.

33. Guthold R, Stevens GA, Riley LM, Bull FC. Worldwide trends in insufficient physical activity from 2001 to 2016: a pooled analysis of 358 population-based surveys with 1,9 million participants. Lancet Glob Health. 2018; 6: e1077-86. https://doi.org/10.1016/S2214-109X(18)30357-7

34. Guthold R, Stevens GA, Riley LM, Bull FC. Global trends in insufficient physical activity among adolescents: a pooled analysis of 298 population-based surveys with 1,6 million participants. Lancet Child Adolesc Health. 2020; 4: 23-35. https://doi.org/10.1016/S2352-4642(19)30323-2

35. World Health Organization. Global recommendations on physical activity for health. Geneva: World Health Organization; 2010.

36. World Health Organization. Prevalence of noncommunicable disease risk factors in Belarus. STEPS 2016. Copenhagen: World Health Organization Regional Office for Europe; 2017.

37. Karzunova A, Belyaeva YU, Zotova A. [Features of physical activity of modern students and student youth]. Bulletin of Medical Internet Conferences. 2016; 6(5): 543-544 (in Russian).

38. Leyfa A. [The social basis of the development of physical activity of students in terms of their quality of life]. Physical Education of Students. 2013; 3: 35-41. https://doi.org/10.6084/m9.figshare.662600 (in Russian).

39. Orlova G, Shemetova G, Nevzorov A, Molodtsov R. [Differentiated approach to prophylaxis among students]. Saratov Journal of Medical Scientific Research. 2011; 7(4): 925-929 (in Russian).

40. Bull FC, Al-Ansari SS, Biddle S, Borodulin K, Buman MP, Cardon G, et al. World Health Organization 2020 guidelines on physical activity and sedentary behaviour. Br J Sports Med. 2020; 54: 1451-1462. https://doi.org/10.1136/bjsports-2020-102955

41. Troiano RP, Stamatakis E, Bull FC. How can global physical activity surveillance adapt to evolving physical activity guidelines? Needs, challenges, and future directions. Br J Sports Med. 2020; 54: 1468-1473. https://doi.org/10.1136/bjsports-2020-102621 
42. Mazur J, Małkowska-Szkutnik A. [HBSC 2010 research results. Technical report]. Warszawa: Instytut Matki i Dziecka; 2011 (in Polish).

43. Sallis JF, Prochaska J, Taylor W. A review of correlates of physical activity of children and adolescents. Medicine and Science in Sports and Exercise. 2000; 32: 963-975 https://doi.org/10.1097/00005768-200005000-00014

44. Świderska-Kopacz J, Marcinkowski JT, Jankowska K. [Health behaviour of secondary school pupils and its chosen determinants. Part V. Physical activity]. Probl Hig Epidemiol. 2008; 89(2): 246-250 (in Polish).

45. Krishnakumer P, Krishna P, Rasu T. Prevalence and patterns of physical activity among medical students in Bangalore, India. Electronic Physician. 2013; 5(1): 606-610.

46. Bergier B, Bergier J, Paprzycki P. Level and determinants of physical activity among school adolescents in Poland. Annals of Agricultural and Environmental Medicine. 2014; 21(1): 75-78. https://doi.org/10.5604/12321966.1120612

47. Cocca A, Cocca M, Gurrrola OC, Chmelik F, Frömel K. Social and environmental predictors of physical activity in Mexican adolescents. Proceedings of ICERI 8th International Conference of Education, Research and Innovation; 2015 Nov 16-18; Seville, Spain. Valencia: IATED; 2015. p. 2672-2681.

48. Baker BL, Birch LL, Trost SG, Davison KK. Advanced pubertal status at age 11 and lower physical activity in adolescent girls. J Pediatr. 2007; 151: 488-493. https://doi.org/10.1016/j.jpeds.2007.04.017

49. Eaton DK, Kann L, Kinchen S. Youth risk behavior surveillance - United States, 2007. MMWR Surveill Summ. 2008; 57: 1-131.

50. World Health Organization. Global action plan on physical activity 2018-2030: more active people for a healthier world. Geneva: World Health Organization; 2018.

51. DiPietro L, Al-Ansari SS, Biddle SJH, Borodulin K, Bull FC, Buman MP, et al. Advancing the global physical activity agenda: recommendations for future research by the 2020 WHO physical activity and sedentary behavior guidelines development group. Int J Behav Nutr Phys Act. 2020; 17:143.

https://doi.org/10.1186/s12966-020-01042-2 